\title{
Analysis of the Complex Index of Extruded Corn Starch and Degermed Corn
}

\author{
Chengye Ma ${ }^{1}$, Yuyan Fan ${ }^{1}$, Shuhua $\mathrm{Wu}^{1}$, Zhehao Zhang ${ }^{1}$ \& Dongliang Zhang ${ }^{1}$ \\ ${ }^{1}$ School of Agricultural Engineering and Food Science, Shandong University of Technology, Zibo, China \\ Correspondence: Chengye Ma, School of Agricultural Engineering and Food Science, Shandong University of \\ Technology, Zibo, China. E-mail: mcycn2002@163.com
}

\author{
Received: July28, 2014 \\ Accepted: August11, $2014 \quad$ Online Published: October 30, 2017 \\ doi: 10.5539/jfr.v6n6p56 \\ URL: https://doi.org/10.5539/jfr.v6n6p56
}

\begin{abstract}
Commercial corn starch or degermed corn contains lipids and protein, and starch-lipid (or protein) complexes were formed during extrusion. The formation of starch and lipid (or protein) complexes was investigated using the complex index (CI) and differential scanning calorimetry (DSC) analysis. The CI of extrudates of a commercial corn starch/germ mixture (or gluten meal) showed that starch was complexed with lipid or protein, thus decreasing the iodine-binding capacity of amylose. The $\mathrm{CI}$ increased as the content of germ or gluten meal blending starch increased. Blends containing degermed corn and thermostable or mesophilic $\alpha$-amylase were extruded. The CI of extrudates was higher than 55\%; however, the starch-lipid complex was not stable and could be separated. The DSC analysis of the blending starch extrudate and palmitic acid showed that the enthalpy of the starch-palmitic acid complex was increased with increasing fatty acid content. Increased complex formation required more DSC heating, resulting in an enthalpy change of the endothermic peak rise, with the peak temperature higher than $100^{\circ} \mathrm{C}$.
\end{abstract}

Keywords: starch-lipid complex, extrusion, corn starch, complex index, DSC

\section{Introduction}

Starch granules are composed of two types of alpha-glucan, namely amylose and amylopectin. Amylose is a relatively long, linear alpha-glucan containing around $99 \%(1 \rightarrow 4)-\alpha$ - and $(1 \rightarrow 6)$-alpha-linkages, which is also a left-hand helix stabilized by inter-helical hydrogen bonds (Richard et al., 2004). The glucosyl hydroxyl groups are located at the outer surface of the helix, while the inner surface is lined with methylene groups and glycosidic oxygen, resulting in a more hydrophobic cavity, similar to that of cyclodextrins (Immel et al., 2000). Amylose complexes with certain agents such as iodine, lipids, dimethylsulfoxide (DMSO), alcohols, flavour compounds, etc. (Bule'on et al., 1998). The driving force for complex formation is presumably its hydrophobic nature and involves transferring the hydrophobic guest molecule from water to the less polar environment within the amylose helix. The most common types of corn granules contain $71 \%$ starch, more than $5 \%$ lipid, about $10 \%$ protein and $14 \%$ water. The relative weight percentages of amylopectin and amylase are $74 \%$ and $26 \%$, respectively. According to the mechanization of complex formation, the starch-lipid complex is formed during extrusion (De Pilli et al., 2008).

Mercier studied the principle of complexing cassava starch, potato starch and corn starch with a native lipid, $12 \mathrm{C}-20 \mathrm{C}$ saturated and unsaturated fatty acids, glyceryl monostearate and sodium stearoyl lactate. The hydrosolubilization and hydrolysation by $\alpha$-amylase decreased upon the formation of the complex (Mercier et al., 1980). During the extrusion of starchy food, starch is gelatinized, protein is denatured and starch complexes with lipids (Bhatnagar et al., 1994; Thachil et al., 2014). Most of the lipids were complexed with starch and protein during extrusion, and the content of raw lipids decreased due to the formation of the starch-lipid complex (Sun et al., 1997). Low molecular weight agents (such as alcohols and lipids) can form a complex with 6 times the weight of amylose, and theoretically, $0.5 \%$ lipids and 3\% amylose can form a complex. An increasing lipid content in commercial starch effectively occupies more amylase. The hydrolysation of starch was decreased in the starch-lipid complex (Eliasson, 1985). An in vitro hydrolysation model of the intestinal canal showed starch in the starch-lipid complex was degraded more slowly. The degree of starch-lipid complexation has also been investigated.

Complexes were formed by adding one part emulsifier to five parts cooked (w/w) non-waxy and waxy rice 
starch (21\% amylose and 79\% amylopectin) solution. The complex index (CI) of the starch-monoglyceride complex (73.4\% C18:0, 23.6\% C16:0) and starch-triglyceride complex (3.0\% C18:0, 19.0\% C18:1, 55\% C18:2, 22.0\% C16:0) were $85 \pm 4.5 \%$ and $81.3 \pm 10.3 \%$, respectively (Harmeet, 1997). Amylose fractions of differing peak degrees of polymerisation (DP) (DP20, DP60, DP400, DP950) were complexed with docosanoic acid (C22) and glyceryl monostearate (GMS) at $60^{\circ} \mathrm{C}$ and $90^{\circ} \mathrm{C}$. Complexation yields increased upon increasing amylose chain length (Gelders et al., 2004). Starch-lipid complexes were formed by mixing wheat starch and various fatty acids and monopalmitin in a rapid visco analyser. The inclusion of the lipids in the starch pastes decreased the holding viscosity, whereas the final viscosity was increased. Above a certain concentration, some of the lipids tend to self-associate in preference to forming a starch-lipid complex (Mary et al., 2007).

Differential scanning calorimetry (DSC) was used to characterize the starch-lipid complexes. A mixture of wheat and glyceryl monostearate were extruded. From the DSC results, the peak appearing at $116^{\circ} \mathrm{C}$ and $132^{\circ} \mathrm{C}$ were considered the endothermic peaks of the amylose-lipid complex (Galloway et al., 1989). Native sago starch was incubated at $60^{\circ} \mathrm{C}$ with lysophosphatidylcholine, monomyristin, monopalmitin and monostearin. DSC peaks centred at $100 \pm 120^{\circ} \mathrm{C}$, indicated the formation of an amylose-lipid complex. The bioavailability of native and freshly gelatinized sago starch was decreased in the presence of lipids, while retrograded starch-lipid samples showed higher digestibility than the starch control (Cui et al., 1999).

The amylose content of degermed corn used in the trial was $26.12 \%$ and the lipid content was $1.04 \%$. The temperature of extrusion was lower than $90^{\circ} \mathrm{C}$, thus the starch and lipids could form a complex during the extrusion of degermed corn or native degermed corn upon the addition of amylase. The formation of starch-lipid (or protein) complexes was investigated by combining the DSC endothermic peak data and CI.

\section{Material and Methods}

Material The degermed corn was purchased from the Baodi Corn Processing Factory. According to our measurements, the moisture, starch, protein and crude fat content were determined to be $12.77 \%(\mathrm{w} / \mathrm{w}), 75.36 \%$, $8.25 \%$ and $1.04 \%$, respectively.

The corn starch was obtained from the Xiwang Group, and the moisture, starch, protein and crude fat content were $13.56 \%(\mathrm{w} / \mathrm{w}), 88.54 \%, 0.28 \%$ and $0.48 \%$, respectively. The gluten meal was purchased from the Xiwang Group, and the moisture, starch, protein, crude fat and fibre content were $11.63 \%, 18.14 \%, 54.81 \%, 5.39 \%$ and $8.38 \%$, respectively. The total fat of the gluten meal was extracted using petroleum ether by means of a Soxhlet extractor. The corn germ was purchased from the BLB Group Co. Ltd, and the moisture, starch, protein, crude fat and fibre content were $10.37 \%, 4.36 \%, 28.55 \%, 53.48 \%$ and $2.68 \%$, respectively.

All of the materials were ground using a grain crusher (FZ102, Taisite Instrument Co. Ltd) to pass through a 100-mesh screen, except corn germ which was passed through an 80-mesh screen.

Thermostable $\alpha$-amylase was purchased from the Shandong Longda Bio-technology Co. Ltd (the bioactivity was $20000 \mathrm{u} / \mathrm{ml}$ ). Mesophilic $\alpha$-amylasewas purchased from Shandong Longda Bio-technology Co. Ltd (the bioactivity was $2000 \mathrm{u} / \mathrm{ml}$ ). The glucoamylase was purchased from the Yangshao Biochemical Engineering Co. Ltd (the bioactivity was $100000 \mathrm{u} / \mathrm{ml}$ ).

Single-screw extruder A single-screw extruder was used in the experiments and the sleeve structure diagram is shown in Figure 1. The extruder consists of a modular sleeve (three pieces) and screw (four pieces), with a productivity of $100 \mathrm{~kg} / \mathrm{h}$. The screw rotation speed was $0 \sim 300 \mathrm{r} / \mathrm{min}$, stepless adjustable. The sleeve was held at a temperature of $0 \sim 300^{\circ} \mathrm{C}$, which was adjustable, and was equipped with an automatically controlled closed-loop digital instrumentation system. The clearance between the templates and screw top was adjustable as was the die diameter of the extruder.

The preparation of extruded corn starches with germ or gluten meal The corn starch and germ (or gluten meal) mixture was adjusted to a moisture content of $20.0 \%(\mathrm{w} / \mathrm{w})$ and extruded. The barrel temperature, screw speed and die diameter used during extrusion are shown in Tables 1 and 2. The extrudates were cooled to room temperature and ground to pass through a 100-mesh screen, then sealed in polyethylene bags until measurements were taken. 


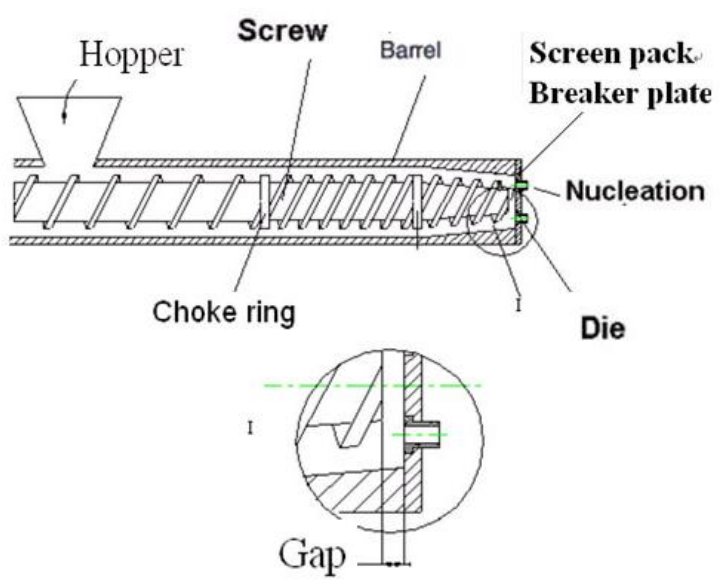

Figure 1. Schematic diagram of a single-screw extruder

The preparation of extruded native degermed corn or extruded degermed corn with added amylase Degermed corn $(1000 \mathrm{~g})$ was mixed with $200-300 \mathrm{~g}$ water and the mixture extruded in a single-screw extruder with thermostable $\alpha$-amylase or mesophilic $\alpha$-amylase. The extrudates were ground to pass through a 100 -mesh screen, and studied using DSC and CI in order to measure the starch-lipid complex.

Complex index analysis The CI determines the degree of starch-lipid complex formation. The CI was measured using the method of Singh and Gelders (Singh et al., 2004; Gelders et al., 2004) with the following modifications.

The ground sample $(0.5 \mathrm{~g})$ was mixed with $25 \mathrm{ml}$ of boiling water in a $50 \mathrm{ml}$ capped tube. The tube was put into a boiling water bath for $5 \mathrm{~min}$ and vortexed every $1 \mathrm{~min}$. The test tube was centrifuged for $20 \mathrm{~min}$ at $3000 \mathrm{r} / \mathrm{min}$. The supernatant $(50 \mathrm{ul})$ and distilled water $(15 \mathrm{ml})$ were added to the iodine solution $(2 \mathrm{ml})$. The tube was inverted several times and the absorbance was measured at $690 \mathrm{~nm}$. The control sample, containing only distilled water, was used as a reference. The CI was calculated using Eq. 1:

$$
\mathrm{CI}(\%)=\frac{\text { absorbance of control }- \text { absorbance of samples }}{\text { absorbance of control }} \times 100
$$

The iodine solution used for this assay was prepared by dissolving potassium iodide $(2 \mathrm{~g})$ and $\mathrm{I}_{2}(1.3 \mathrm{~g})$ in distilled $(50 \mathrm{ml})$ water and allowing it to dissolve overnight. Distilled water was added to make a final volume of $100 \mathrm{ml}$.

Differential scanning calorimetry DSC was performed with a TA DSC Q100 (TA Instrument Inc., USA).

A sample to water ratio of $1: 3$ was used and the sample slurries were equilibrated overnight at room temperature to distribute the water evenly in the sample. The sample slurries $(10-20 \mathrm{mg})$ were accurately weighed into coated aluminium sample pans. The pans were sealed and weighed, the sample pan and an empty reference pan were heated from 20 to $200^{\circ} \mathrm{C}$ at $10^{\circ} \mathrm{C} / \mathrm{min}$. The calorimeter was equipped with a nitrogen gas purge and the rate of gas flow was $50.0 \mathrm{ml} / \mathrm{min}$.

\section{Results and Discussion}

The CI determines the degree of starch-lipid complex formation. The portion of the starch bound by lipid will not bind iodine, therefore, the absorbance is related to the portion of starch that is complexed to the iodine. A linear correlation was found between weight of the complex and the CI.

Starch is a major constituent of corn, and the formation of a starch-lipid complex affects gelatinization and hydrolysis, leading to a decreased amount of hydrolysate. The aim of this study was therefore to investigate the formation of the starch-lipid complex.

The CI of the extrudates of the commercial starch mixed with gluten meal and (or) germ are shown in Table 1. Starch was complexed with lipid and protein, and produced a new material which lowered the ability of starch to bind iodine.

Trials No.1 and No.4 (Table 1) show an increased CI of extrudates as the gluten content ratio to starch was increased. The complex formed was determined to be a starch-protein complex, as the fat of the gluten meal was 
extracted with petroleum ether. Trials No.2 and No.4 show an increased CI of extrudates as the ratio of germ content added to starch was increased. The CI also increased as the barrel temperature was raised. The lipids were degraded to fatty acids during extrusion, which complexed with amylose and formed the amylose-fatty acid complex. After the corn was extruded, the crude fat content decreased and the combined fat content increased, with a positive correlation to its degree of gelatinization (Sun et al., 1997). Mixing wheat starch with caprylic acid, lauric acid, myristic acid, palmitic acid, stearic acid, oleic acid, linoleic acid, linolenic acid and monopalmitin showed that maximal complex formation occurred at a different concentration for each lipid (Tang et al., 2006).

Table 1. CI of extruded corn starch mixed with corn gluten meal or germ

\begin{tabular}{lllllllll}
\hline No. & Materials & $\begin{array}{l}\text { Ingredient } \\
\text { Percentage }(w / w)\end{array}$ & $\begin{array}{l}\text { Moisture } \\
\text { Content }(\%)\end{array}$ & $\begin{array}{l}\text { Starch } \\
\text { Content }(\%)\end{array}$ & $\begin{array}{l}\text { Fat } \\
\text { Content }(\%)\end{array}$ & $\begin{array}{l}\text { Protein } \\
\text { Content }(\%)\end{array}$ & $\begin{array}{l}\text { Barrel } \\
\text { Temperature }\left({ }^{\circ} \mathrm{C}\right)\end{array}$ & CI \\
\hline 1 & starch+gluten meal & $8.8: 1$ & 21.96 & 78.66 & 0.98 & 5.84 & 60.0 & 12.55 \\
2 & starch-germ & $8.4: 1$ & 22.00 & 76.90 & 6.12 & 3.29 & 60.0 & 12.76 \\
3 & starch-gluten meal-germ & $7.3: 1.1: 1$ & 21.94 & 69.56 & 6.71 & 9.18 & 60.0 & 14.17 \\
4 & starch-gluten meal & $1: 1$ & 25.70 & 51.84 & 2.94 & 27.55 & 80.0 & 38.32 \\
5 & starch-germ & $1: 1$ & 22.00 & 44.95 & 26.98 & 14.42 & 80.0 & 28.89 \\
6 & starch-glutenmeal-germ & $1: 1: 1$ & 22.00 & 36.01 & 19.78 & 27.88 & 80.0 & 36.45 \\
7 & extruded starch & & 30.00 & & 0.48 & & 60.0 & 8.05 \\
\hline
\end{tabular}

Notes to Table 1: the screw speed was $110 \mathrm{r} / \mathrm{min}$ and the nozzle diameter was $12 \mathrm{~mm}$.

Table 2. CI and DSC enthalpy of extruded native and added degermed corn flour

\begin{tabular}{|c|c|c|c|c|c|c|c|}
\hline \multirow[t]{2}{*}{ No. } & \multirow[t]{2}{*}{ Amylase type } & \multirow{2}{*}{$\begin{array}{l}\text { Amylase amount } \\
(\mathrm{L} / \mathrm{t})\end{array}$} & \multirow{2}{*}{$\begin{array}{l}\text { Barrel } \\
\text { temperature }\left({ }^{\circ} \mathrm{C}\right)\end{array}$} & \multirow[t]{2}{*}{ CI (\%) } & \multicolumn{3}{|l|}{ DSC diagram } \\
\hline & & & & & $\begin{array}{l}\text { Onset } \\
\text { temperature }\left({ }^{\circ} \mathrm{C}\right)\end{array}$ & $\begin{array}{l}\text { Peak temperature } \\
\left({ }^{\circ} \mathrm{C}\right)\end{array}$ & $\begin{array}{l}\text { Enthalpy change } \\
\Delta H(\mathrm{~J} / \mathrm{g})\end{array}$ \\
\hline$\overline{1}$ & Extruded degermed & & 50 & 11.30 & 1 & 1 & 1 \\
\hline 2 & & & 60 & 21.30 & 100.64 & 112.63 & 754.0 \\
\hline 3 & & & 75 & 40.51 & I & & I \\
\hline 4 & Mesophilic $\alpha$-amylase & 10.0 & 50 & 88.46 & I & l & I \\
\hline 5 & & 10.0 & 60 & 89.20 & I & I & I \\
\hline 6 & & 10.0 & 75 & 84.61 & 90.03 & 111.38 & 1173 \\
\hline 7 & Thermostable $\alpha$-amylase & 1.0 & 50 & 56.54 & I & I & I \\
\hline 8 & & 1.0 & 60 & 66.39 & 96.35 & 116.67 & 1022 \\
\hline 9 & & 1.0 & 70 & 61.72 & I & l & I \\
\hline 10 & Native degermed & & & & 101.57 & 114.95 & 702.3 \\
\hline
\end{tabular}

Notes to Table 2: screw speed was $110 \mathrm{r} / \mathrm{min}$, the nozzle diameter was $12 \mathrm{~mm}$ and the material moisture content was $30 \%$.

The fat content in native starch was $0.48 \%$, which was the lowest among the samples and the CI of the extrudates was $8.05 \%$, which was the lowest among the extrudates.

DSC is a valuable method for obtaining information on the properties of starch. The amylose-lipid complex transition occurs upon the heating of starch, and the interaction of starch with lipids influences gelatinization and the endothermal thermogram.

DSC results show that complexation of starch with lipids or protein occurred during extrusion, as evidenced by the endothermic transitions from 100 to $140^{\circ} \mathrm{C}$ (Figures 2-4).

Gelatinization is the major transition of starch during thermal processes. The enthalpy of the extruded degermed corn was more than that of extruded degermed corn with thermostable $\alpha$-amylase or mesophilic $\alpha$-amylase. The results confirm that the starch-lipid complex was formed. During extrusion, the crystalline structure of the granules was broken down allowing chemical and biological activity, and the starch was degraded into oligosaccharides. If the amylose and amylopectin chains became vulnerable, gelatinization would occur; the starch would then be ready for liquefaction. $\alpha$-amylase divides the macromolecules, breaking down the macromolecular structure and converting the remaining starch fractions into oligosaccharides. The helical structure of amylose is the foundation of amylose-lipid complexation, and three turns of the amylose helix (six glucosyl units per turn) are required to complex with an FFA molecule (Zhang et al. 2003). Further helices were made after extrusion and more starch-lipid or starch-protein complexes were formed. Thus, the enthalpy and CI of extruded native degermed corn was less than that of extruded native degermed corn with $\alpha$-amylase.

The starch content in degermed corn was $75 \%$, the amylose content of degermed corn and commercial starch were 
$26 \%$ and $19.5 \%$, respectively.

According to the minimal CI value of extrudates (56.54\%), $11.03 \%$ of the starch would complex with lipids. However, the DE value of extrudates (after saccharification) was higher than $89 \%$ and the conversion percentage of starch was higher than $>90 \%$, which showed that the starch-lipid complex was unstable and could be separated.

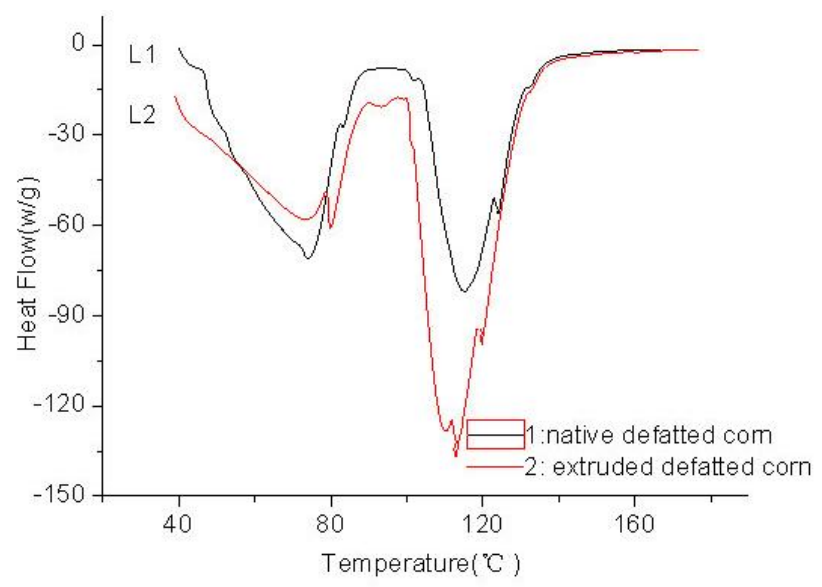

Figure 2. DSC diagram of native and extruded degermed corn

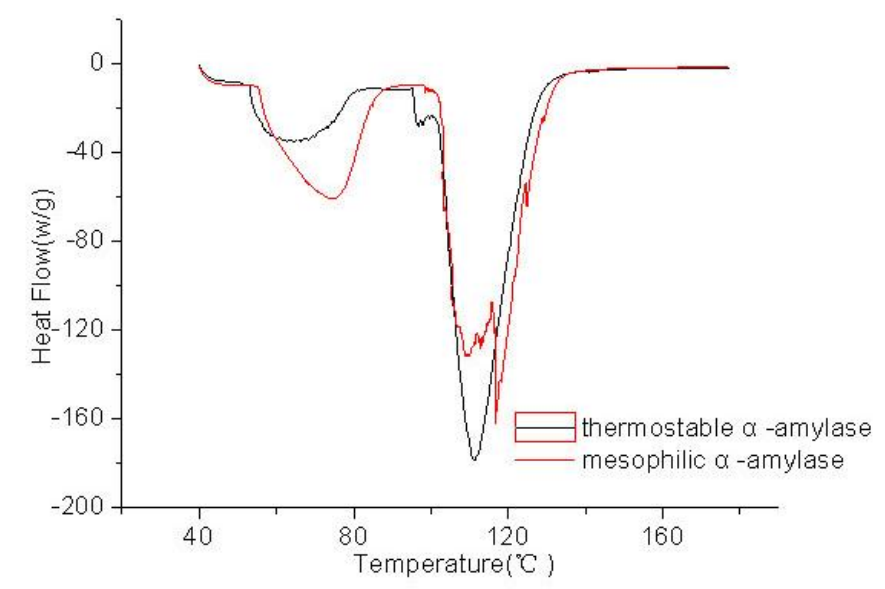

Figure 3. DSC diagram of extruded degermed corn with added enzyme

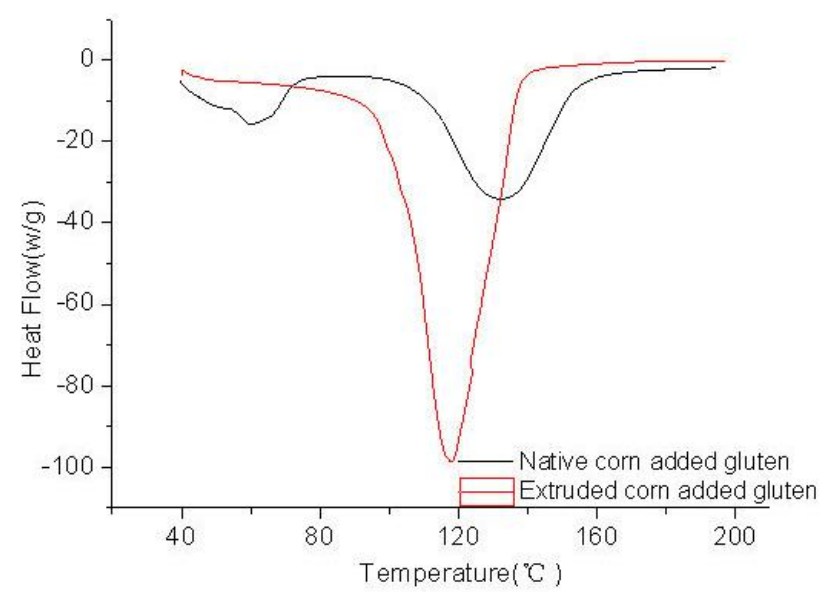

Figure 4. DSC diagram of native and extruded degermed corn with added gluten meal.

The enthalpy change of degermed corn (Trial No. 10, Table 2) was the lowest, and that of extruded degermed corn was next lowest. The enthalpy change of extrudates from degermed corn with amylase was larger than that 
of extruded degermed corn (or native degermed corn), which showed that the complex was formed during extrusion and was confirmed by the CI.

\section{Conclusion}

Starch-lipid complexes were formed during extrusion, and the CI increased as the germ content was increased. The starch-protein complexes were formed during extruding the mixture of degermed and gluten. The DSC results show that starch-lipid and starch-protein complexes were formed during extrusion. According to the minimal CI and DE value of extrudates, the starch-lipid (or protein) complex was unstable and could be separated. The complex could be separated if amylase and starch was hydrolysed to saccharides; however, the mechanization of starch-lipid (or protein) complex formation requires further investigation.

\section{Acknowledgements}

This research was funded by Natural Science Foundation of China (No: 31471676), Higher education superior discipline team training program of Shandong Province. The authors would like to thank to Lina Wang, Weiwei Chang, Xiaowen Wang, Yongzai Wang, Fazhe Sun and for help in instrument operation.

\section{References}

Bhatnagar, S., \& Hanna, M. A. (1994). Amylose-lipid complex formation during single screw extrusion of various corn starches. Cereal Chemistry, 71, 582-587.

Bule'on, A., Colonna, P., Plancho, V., \& Ball, S. (1998). Starch granules: structure and biosynthesis. International Journal of Biological Macromolecules, 23, 85-112. https://doi.org/10.1016/S0141-8130(98)00040-3

Cui, R., \& Oates, C. G. (1999). The effect of amylose-lipid complex formation on enzyme susceptibility of sago starch. Food Chemistry, 65, 417-425. https://doi.org/10.1016/S0308-8146(97)00174-X

De Pilli, T., Jouppila, K., Ikonem, J., Kansikas, J., Derossi, A., \& Severini, C. (2008). Study on formation of starch-lipid complexes during extrusion-cooking of almond flour. Journal of Food Engineering, 87, 495-504. https://doi.org/10.1016/j.jfoodeng.2007.12.028

Galloway, G. I., Biliaderis, C. G., \& Stanley, D. W. (1989). Properties and Structure of Amylose-glyceryl monostearate complex formed in solution or on extrusion of wheat flour. J. Food Science, 54, 950-957. https://doi.org/10.1111/j.1365-2621.1989.tb07920.x

Gelders, G. G., Vanderstukken, T. C., Goesaert, H., \& Delcour, J. A. (2004). Amylose-lipid complexation: a new fractionation method. Carbohydrate Polymer, 56, 447-458. https://doi.org/10.1016/j.carbpol.2004.03.012

Godet, M. C., Bouchet, B., Colonna, P., Gallant, D. J., \& Buleon, A. (1996). Crytstalline amylose-fatty acid complex: morphology and crystal thickness. Journal of Food Science, 61, 1196-1201. https://doi.org/10.1111/j.1365-2621.1996.tb10959.x

Guraya, H. S., Kadan, R. S., \& Champagne, E. T. (1997). Effect of rice starch-lipid complex on in vitro digestibility, complexing index, and viscosity.Cereal Chemistry, 74, 561-565. https://doi.org/10.1094/CCHEM.1997.74.5.561

Larsson, I., \& Eliasson, A. C. (1991). Annealing of starch at an intermediate water content.Starch, 43, 227-231. https://doi.org/10.1002/star.19910430606

Mercier, C., Charbonniere, R., Grebaut, J., \& Gueriviere, J. F. (1980). Formation of amylose lipid complex by twin-screw extrusion cooking of manioc starch. Cereal Chemistry, 57, 4-9.

Narpinder, S., Kulwinder, K., Hardeep, S., \& Harmeet, S. (2000). Effect of starch-lipids inclusion complex formation on functional properties of flour in tandoor roti. Food Chemistry, 69, 129-13. https://doi.org/10.1016/S0308-8146(99)00229-0

Richard, F. T., Karkalas, J., \& Qi, X. (2004). Starch-composition, fine structure and architecture.Journal of Cereal Science, 39, 151-165. https://doi.org/10.1016/j.jcs.2003.12.001

Sun, F. L., Zhu, q., Wang X. F., \& Fang W. M. (1997). Studies on the extrusion gelatinization degree of corn and fat content. Journal of Zhengzhou Institute Technology, 18, 34-37.

Tang, M. C., \& Copeland, L. (2007). Analysis of complex between lipids and wheat starch. Carbohydrate Polymer, 67, 80-85. https://doi.org/10.1016/j.carbpol.2006.04.016

Thachil, M. T., Chouksey, M. K., \& Gudipati, V. (2014). Amylose-lipid complex formation during extrusion cooking: effect of added lipid type and amylose level on corn-based puffed snacks. International Journal of 
Food Science and Technology, 49, 309-316. https://doi.org/10.1111/ijfs.12333

Zhang, G., Maladen, M., \& Hamaker, B. R. (2003). Detection of a novel three-way complex consisting of starch, protein, and free fatty acids.Journal of Agricultural and Food Chemistry, 51, 2801-2805.

https://doi.org/10.1021/jf030035t

\section{Copyrights}

Copyright for this articleis retained by the author(s), with first publication rights granted to the journal.

This is an open-access article distributed under the terms and conditions of the CreativeCommons Attribution license (http://creativecommons.org/licenses/by/4.0/). 